\title{
Pengaruh Beauty Vlogger, Citra Merek Dan Label Halal Terhadap Minat Beli Produk Kosmetik Wardah
}

\author{
Nur Hidayati ${ }^{1}$, Linda Yuliandani ${ }^{2}$ \\ Program Studi Manajemen ${ }^{1,2}$ \\ Universitas Pelita Bangsa, \\ Email: nur@pelitabangsa.ac.id ${ }^{1}$, lindayuliandani5@gmail.com ${ }^{2}$
}

\begin{abstract}
ABSTRAK
Pesatnya perkembangan teknologi komunikasi dan informasi menyebatkan terjadinya value migration dari penggunaan surat sebagai sarana telekomunikasi fisik ke telekomunikasi digital. Kemunculan beauty vlogger akan memberikan pengaruh pada industri kecantikan, baik untuk perusahaan penghasil produk kecantikan, beauty vlogger itu sendiri, dan mempengaruhi minat beli konsumen. Kosmetik merek lokal masih menjadi raja dinegeri sendiri.

Pendekatan penelitian yang digunakan dalam penelitian ini adalah analisis deskriptif dengan menggunakan data kuesioner. Teknik sampling yang digunakan adalah probability sampling dengan metode purposive sampling. Analisis yang digunakan dalam Penelitian adalah uji asumsi klasik, analisis regresi berganda, koefisien determinasi, pengujian hipotesis dengan menggunakan uji t. adapun teknik pengambilan sampling yang digunakan adalah purposive sampling. Hasil pengujian menggunakan uji $\mathrm{t}$ sebagai berikut: Beauty vlogger berpengaruh secara signifikan terhadap Minat Beli, Citra Merek berpengaruh secara signifikan terhadap Minat Beli, Lokasi berpengaruh secara signifikan terhadap Minat Beli.
\end{abstract}

Kata Kunci : Beauty vlogger, Citra Merek, Label Halal, Minat Beli

\section{ABSTRACT}

The rapid development of communication and information technology has argued about the occurrence of value migration from the use of letters as a means of physical telecommunications to digital telecommunications. The emergence of a beauty vlogger will have an influence on the beauty industry, both for companies producing beauty products, the beauty vlogger itself, and affect consumer buying interest. Local brand cosmetics are still the kings of their own country.

The research approach used in this research is descriptive analysis using questionnaire data. The sampling technique used is probability sampling with a purposive sampling method. The analysis used in the study is the classic assumption test, multiple regression analysis, coefficient of determination, hypothesis testing using the $t$ test. The sampling technique used was purposive sampling. The test results using the $t$ test as follows: Beauty vlogger significantly influences Buy Intention, Brand Image significantly influences Buy Intention, Location significantly influences Buy Intention.

Keywords: Beauty vlogger, Brand Image, Halal Label, Purchase Interest 


\section{PENDAHULUAN}

Perkembangan teknologi yang semakin canggih telah membawa banyak pengaruh ke segala aspek kehidupan, salah satunya pada teknologi komunikasi dan informasi. Pesatnya perkembangan teknologi komunikasi dan informasi menyebatkan terjadinya value migration dari penggunaan surat sebagai sarana telekomunikasi fisik ke telekomunikasi digital (Lambang, 2015:82). Hal ini ditandai dengan setiap orang di seluruh dunia dapat saling terhubung dengan perkembangan satelit, telepon, dan internet. Teknologi komunikasi terutama internet membuat informasi semakin cepat menyebar dan dapat diakses siapa saja, kapan saja, dan dimana saja. Perkembangan teknologi komunikasi dan informasi telah melahirkan sebuah media komunikasi dan informasi yang saat ini sangat diminati masyarakat, yaitu media sosial. Media sosial mempunyai pengaruh pada pelaku pasar untuk berkomunikasi dengan sesama produsen, pelanggan atau calon pelanggan (Kurniawati, et al 2015). Di Indonesia penggunaan internet saat ini mayoritas digunakan untuk mengakses media sosial, hal ini dibuktikan dengan hasil survei yang dilakukan oleh Asosiasi Penyelenggara Jasa Internet Indonesia (APJII) pada tahun 2016.

Berdasarkan data yang di peroleh APJII diketahui 97,4\% pengguna internet di Indonesia mengakses media sosial, salah satu media sosial yang paling banyak diakses periode 2016 adalah youtube. Media sosial tidak hanya menjadi sebuah tempat untuk menunjukkan diri atau mengekspresikan diri terhadap dunia luar namun juga sebagai tempat untuk mendapatkan banyak informasi (Febriana, et al 2018). Berbagai macam media sosial yang muncul saat ini seperti Twitter, Facebook, Instagram, dan Youtube dimanfaatkan konsumen untuk mendapatkan informasi.

Youtube menjadi salah satu media sosial yang digemari banyak orang pada saat ini. Youtube hadir dalam bentuk audio dan visual yang membuat informasi yang didapatkan semakin jelas dan nyata.

Berdasarkan Hasil Survei Asosiasi Penyelenggara Jasa Internet Indonesia (APJII) th 2016 diketahui bahwa saat ini Youtube termasuk kedalam 3 besar media sosial yang sering dikunjungi oleh masyarakat Indonesia dan salah satu konten yang banyak diminati adalah mengenai vlogging kecantikan yang diunggah oleh beauty vlogger. 
Fenomena penggunaan Youtube ini dimanfaatkan oleh para beauty vlogger untuk membuat $v \log$ yang berisi pengalaman mereka dalam menggunakan sebuah produk terutama produk kosmetik dan kecantikan. Vlog sendiri termasuk kedalam electronic word of mouth, yang sangat populer saat ini dan digunakan sebagai salah satu media pemasaran produk (Febriana, et al 2018). Video Log (Vlog) juga dapat berfungsi sebagai suatu media yang dapat membuat beauty vlogger merasa lebih dekat dengan para viewers atau orang yang menyaksikan videonya. Kemunculan beauty vlogger akan memberikan pengaruh pada industri kecantikan, baik untuk perusahaan penghasil produk kecantikan, beauty vlogger itu sendiri, maupun untuk para konsumen dari industri kecantikan.

Merk atau brand lokal merupakan salah satu produk yang patut diperhitungkan karena semakin lama merek lokal semakin diminati, terbukti dengan banyaknya produk baru yang bermunculan. Membangun brand image yang positif dapat dicapai dengan program marketing yang kuat terhadap produk yang unik, dan memiliki kelebihan yang menonjol dibaningkan dengan produk lain (Sunarti, et al 2019). Kosmetik merek lokal masih menjadi raja dinegeri sendiri. Kehalalan akan menjadi penting dalam pemasaran di Indonesia, karena saat ini konsumen akan memperhatikan label halal yang tertera pada produk yang diperjual belikan pada pasar (Widiyaningrum, 2016). PT Paragon Technology Innovative (PTI) yang telah berdiri sejak tahun 1985, yang memiliki banyak brand kecantikan, dan salah satunya wardah sebagai pelopor dalam menciptakan produk kecantikan bersetifikat halal.

Pengaruh hasil review atau rekomendasi yang diberikan oleh beauty vlogger dalam sebuah sharing review akan mampu mempengaruhi minat beli konsumen. Keefektifan beauty vlogger terhadap minat beli konsumen memiliki hal yang menarik untuk diteliti, mengingat pengenalan produk dan evaluasi alternatif adalah hal yang dapat menimbulkan minat beli konsumen (Schiffman dan Kanuk, 2004 ; 25 dalam Sunarti, et al 2019). Penelitian ini untuk mengetahui seberapa besar minat membeli dipengaruhi oleh Beauty vlogger, citra merek dan label halal. 


\section{METODE PENELITIAN}

a. Desain Penelitian

Desain penelitian dalam penelitian ini adapah sebagai berikut:

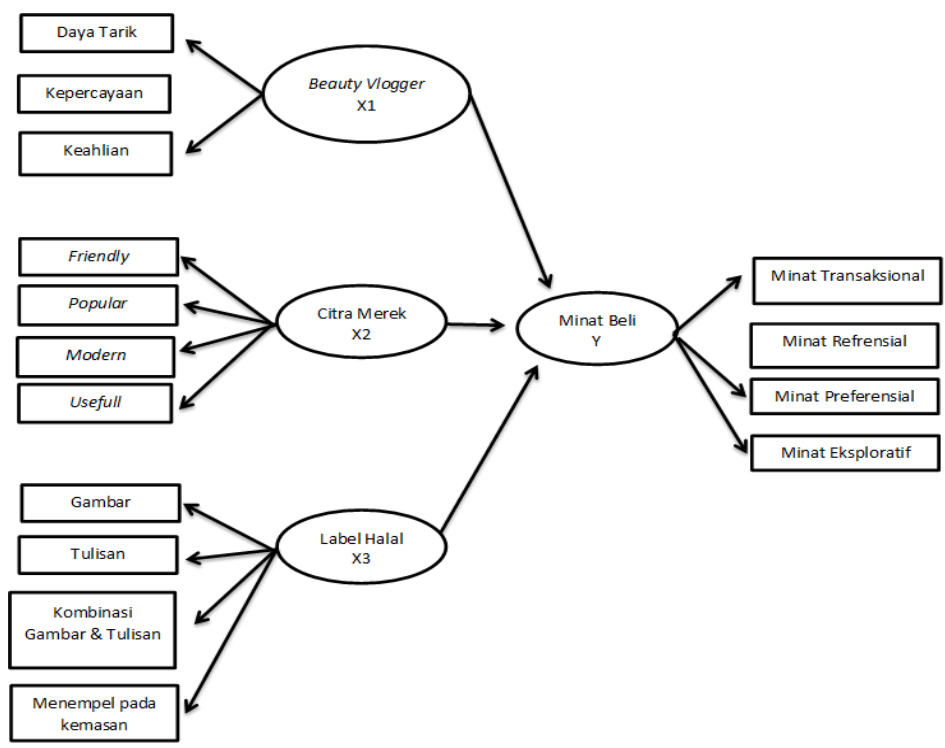

Gambar 1: Desain Penelitian

\section{b. Definisi Operasional Variabel Penelitian}

Adapun definisi Operasional variabel dalam penelitian ini akan dijelaskan pada tabel berikut :

Tabel 1. Definisi Operasional Variabel

\begin{tabular}{|c|c|c|}
\hline Uraian Variabel & Instrumen/Dimensi & $\begin{array}{c}\text { Keterangan / Penjelasan Atas Instrumen Var- } \\
\text { iabel }\end{array}$ \\
\hline \multirow{3}{*}{$\begin{array}{l}\text { Beauty vlogger adalah influ- } \\
\text { encer kecantikan yang } \\
\text { berbagi informasi yang } \\
\text { mengajarkan keterampilan } \\
\text { tertentu dan mengambarkan } \\
\text { bagaimana melakukan } \\
\text { sesuatu dengan konten me- } \\
\text { lalui klip video yang } \\
\text { kemudian di posting pada } \\
\text { platform YouTube. (Choi } \\
\text { dan Behm-Morawitz, } 2017 \\
\text { dikutip dalam Sinaga, } \\
\text { Jusumawati, 2018) }\end{array}$} & Daya Tarik & $\begin{array}{l}\text { Daya Tarik Merupakan hal yang berhub- } \\
\text { ungan dengan nilai sosial dari seseorang } \\
\text { yang meliputi kepribadian, tampilan fisik, } \\
\text { dan memiliki keadaan atau kondisi yang sa- } \\
\text { ma dengan viewers }\end{array}$ \\
\hline & Kepercayaan & $\begin{array}{l}\text { Kepercayaan merupakan kesukaan viewers } \\
\text { terhadap seorang vlogger sehingga akan } \\
\text { mempengaruhi tingkat kepercayaan viewers } \\
\text { terhadap informasi yang diberikan oleh vlog- } \\
\text { ger }\end{array}$ \\
\hline & Keahlian & $\begin{array}{l}\text { Keahlian merupakan hal yang mengacu pada } \\
\text { pengalaman, pengetahuan dan keahlian } \\
\text { seorang vlogger dalam membuktikan } \\
\text { keunggulan dan kekurangan dari sebuah } \\
\text { produk maupun memberikan informasi } \\
\text { produk secara keseluruhan. }\end{array}$ \\
\hline \multirow{2}{*}{$\begin{array}{l}\text { Citra Merek adalah Suatu } \\
\text { Pemahaman atau kepercaya- } \\
\text { aan yang dipegang kon- } \\
\text { sumen terhadap suatu } \\
\text { produk atau merek yang }\end{array}$} & $\begin{array}{l}\text { Friendly (Merek } \\
\text { Mudah Dikenali) }\end{array}$ & $\begin{array}{l}\text { Friendly dimana merk atau produk mudah } \\
\text { untuk dikenal }\end{array}$ \\
\hline & $\begin{array}{l}\text { Popular (Merek } \\
\text { Akrab Dikon- } \\
\text { sumen) }\end{array}$ & $\begin{array}{l}\text { Popular dimana produk atau merek yang } \\
\text { sangat akrab dibenak konsumen }\end{array}$ \\
\hline
\end{tabular}




\begin{tabular}{|c|c|c|}
\hline Uraian Variabel & Instrumen/Dimensi & $\begin{array}{c}\text { Keterangan / Penjelasan Atas Instrumen Var- } \\
\text { iabel }\end{array}$ \\
\hline \multirow{2}{*}{$\begin{array}{l}\text { selalu dipertimbangkan saat } \\
\text { pertama kali mendengar atau } \\
\text { terpikir yang ada dibenak } \\
\text { konsumen (Kotler dan Kel- } \\
\text { ler, } 2008 \text { dikutip dalam } \\
\text { Adriyati, Indriyani, } 2017 \text { ) }\end{array}$} & $\begin{array}{l}\text { Modern (Merek } \\
\text { yang Mengikuti } \\
\text { Perkembangan } \\
\text { jaman) }\end{array}$ & $\begin{array}{l}\text { Modern dimana produk atau merk memiliki } \\
\text { model yang selalu mengikuti jaman }\end{array}$ \\
\hline & $\begin{array}{l}\text { Usefull (Merek } \\
\text { yang bermanfaat) }\end{array}$ & $\begin{array}{l}\text { Usefull bisa merupakan produk atau merk } \\
\text { bermanfaat baik bagi konsumen }\end{array}$ \\
\hline \multirow{4}{*}{$\begin{array}{l}\text { Label Halal bertujuan agar } \\
\text { konsumen mendapatkan per- } \\
\text { lindungan kehalalan dan } \\
\text { kenyamanan atas pemakaian } \\
\text { produk tersebut (Yus- } \\
\text { wohady, 2015:23 dikutip } \\
\text { dalam Tarigan, 2016). }\end{array}$} & Gambar & $\begin{array}{l}\text { Gambar merupakan hasil daro tiruan berupa } \\
\text { bentuk atau pola dibuat dengan coretan alat } \\
\text { tulis. }\end{array}$ \\
\hline & Tulisan & $\begin{array}{l}\text { Tulisan merupakan hasil dari menulis yang } \\
\text { diharapkan bisa untuk dibaca }\end{array}$ \\
\hline & $\begin{array}{l}\text { Kombinasi Gam- } \\
\text { bar dan Tulisan }\end{array}$ & $\begin{array}{l}\text { Kombinasi Gambar dan Tulisan merupakan } \\
\text { gabungan antara hasil gambar dan hasil tuli- } \\
\text { san yang dijadikan menjadi satu bagian }\end{array}$ \\
\hline & $\begin{array}{l}\text { Menempel pada } \\
\text { Kemasan }\end{array}$ & $\begin{array}{l}\text { Menempel pada Kemasan dapat diartikan } \\
\text { sebagai sesuatu yang melekat, (dengan } \\
\text { sengaja atau tidak sengaja) pada kemasan } \\
\text { (pelindung suatu produk) }\end{array}$ \\
\hline \multirow{4}{*}{$\begin{array}{l}\text { Minat Beli adalah respon } \\
\text { yang timbul terhadap suatu } \\
\text { objek yang menunjukkan } \\
\text { keinginan seseorang untuk } \\
\text { melakukan pembelian (Ko- } \\
\text { tler dan Keller, } 2009 \text { dikutip } \\
\text { dalam Adriyati, Indriyani, } \\
\text { 2017) }\end{array}$} & $\begin{array}{l}\text { Minat } \\
\text { Transaksional }\end{array}$ & $\begin{array}{l}\text { Minat Transaksional merupakan keinginan } \\
\text { untuk membeli suati produk tertentu }\end{array}$ \\
\hline & Minat Refrensial & $\begin{array}{l}\text { Minat Referensial merupakan kecenderungan } \\
\text { untuk mereferensikan suatu produk ke orang } \\
\text { lain }\end{array}$ \\
\hline & Minat Preferensial & $\begin{array}{l}\text { Minat Preferensial merupakan gambaran per- } \\
\text { ilaku seseorang yang memiliki prefrensi } \\
\text { utama pada produk tersebut }\end{array}$ \\
\hline & Minat Eksploratif & $\begin{array}{l}\text { Minat Eksploratif merupakan perilaku } \\
\text { seseorang selalu mencari informasi mengenai } \\
\text { produk yang diminatinya dan mencari infor- } \\
\text { masi untuk mendukung sifat-sifat positif dari } \\
\text { produk tersebut sebelum membelinya }\end{array}$ \\
\hline
\end{tabular}

c. Metode Analisis Data

Metode analisis digunakan untuk menginterprestasikan dan menganalisis data adalah uji asumsi klasik, analisis regresi berganda, koefisien determinasi, pengujian hipotesis dengan menggunakan uji t. Sesuai dengan model yang dikembangkan dalam penelitian ini maka alat analisis data yang digunakan adalah program SPSS versi 22.0 .

\section{HASIL DAN PEMBAHASAN}

a. Hasil Uji Validitas dan Uji Realibilitas

Pengujian ini bertujuan untuk mengetahui apakah instrumen yang digunakan valid atau reliabel sebab kebenaran data yang diolah sangat menentukan kualitas hasil penelitian. 
1) Hasil Uji Validitas

Validitas adalah suatu ukuran yang menunjukkan tingkat-tingkat kevalidan suatu instrumen. Variabel dinyatakan valid dapat diketahui dari signifikan pada hasil perhitungan korelasi lebih kecil dari 0,05. Variabel juga dapat dinyatakan valid jika rhitung positif, serta rhitung > rtabel (Santoso, 2005:277 dikutip dalam Hirsa, 2017). Maka hasil uji validitas dapat disajikan sebagai berikut:

Tabel 2. Hasil Uji Validitas Variabel Beauty vlogger (X1)

\begin{tabular}{lllll}
\hline Pernyataan & rhitung & Sig & rtabel & Keterangan \\
\hline X1.1 & 0,812 & 0,000 & 0,1755 & Valid \\
X1.2 & 0,769 & 0,000 & 0,1755 & Valid \\
X1.3 & 0,781 & 0,000 & 0,1755 & Valid \\
\hline
\end{tabular}

Sumber : Data yang diolah SPSS 22, 2019

Berdasarkan tabel tersebut menunjukkan bahwa item-item pernyataan pada variabel-variabel bebas Beauty vlogger, adalah valid.

Tabel 3. Hasil Uji Validitas Variabel Citra Merek (X2)

\begin{tabular}{lllll}
\hline Pernyataan & rhitung & Sig & rtabel & Keterangan \\
\hline X2.1 & 0,851 & 0,000 & 0,1755 & Valid \\
X2.2 & 0,862 & 0,000 & 0,1755 & Valid \\
X2.3 & 0,818 & 0,000 & 0,1755 & Valid \\
X2.4 & 0,844 & 0,000 & 0,1755 & Valid
\end{tabular}

Sumber : Data yang diolah SPSS 22, 2019

Berdasarkan tabel tersebut menunjukkan bahwa item-item pernyataan pada variabel-variabel bebas Citra Merek adalah valid.

Tabel 4. Hasil Uji Validitas Variabel Label Halal (X3)

\begin{tabular}{llll}
\hline Pernyataan & rhitung & Sig & rtabel Keterangan \\
\hline X3.1 & 0,815 & 0,000 & 0,1755 Valid \\
X3.2 & 0,886 & 0,000 & 0,1755 Valid \\
X3.3 & 0,844 & 0,000 & 0,1755 Valid \\
X3.4 & 0,822 & 0,000 & 0,1755 Valid \\
\hline
\end{tabular}

Sumber : Data yang diolah SPSS 22, 2019

Berdasarkan tabel diatas menunjukkan bahwa item-item pernyataan pada variabel-variabel bebas Label Halal adalah valid. 
Tabel 5. Hasil Uji Validitas Variabel Minat Beli (Y)

\begin{tabular}{llll}
\hline Pernyataan & rhitung & Sig & rtabel Keterangan \\
\hline Y.1 & 0,810 & 0,000 & 0,1755 Valid \\
Y.2 & 0,798 & 0,000 & 0,1755 Valid \\
Y.3 & 0,867 & 0,000 & 0,1755 Valid \\
Y.4 & 0,730 & 0,000 & 0,1755 Valid
\end{tabular}

Sumber : Data yang diolah SPSS 22, 2019

Berdasarkan tabel diatas menunjukkan bahwa item-item pernyataan pada variabel-variabel bebas Label Halal adalah valid.

2) Hasil Uji Reliabilitas

Uji reliabilitas adalah suatu indeks yang menunjukkan sejauh mana hasil suatu pengukuran dapat dipercaya. Dasar pengambilan keputusan uji reliabilitas sebagaimana disampaikan oleh Sujarweni (2015:172), antara lain : Jika nilai Cronbach's Alpha $>0,60$, maka item pertanyaan atau pernyataan dalam kuesioner dinyatakan reliabel. Jika nilai Cronbach's Alpha $<0,60$, maka item pertanyaan atau pernyataan dalam kuesioner dinyatakan tidak reliabel. Berikut adalah tabel hasil uji reliabilitas

Tabel 6. Hasil Uji reliabilitas

\begin{tabular}{|l|c|c|c|}
\hline \multicolumn{1}{|c|}{ Variabel } & $\begin{array}{c}\text { Cronbach } \\
\text { Alpha }\end{array}$ & $\begin{array}{c}\text { Reliabilitas } \\
\text { Minimum }\end{array}$ & Keterangan \\
\hline Beauty vlogger & $\mathbf{0 , 7 1 2}$ & 0,60 & Reliabel \\
\hline Citra Merek & $\mathbf{0 , 8 7 6}$ & 0,60 & Reliabel \\
\hline Label Halal & $\mathbf{0 , 8 6 0}$ & 0,60 & Reliabel \\
\hline Minat Beli & $\mathbf{0 , 8 1 4}$ & 0,60 & Reliabel \\
\hline
\end{tabular}

Sumber : Data yang diolah SPSS 22, 2019

Berdasarkan tabel tersebut diperoleh nilai reliabilitas, seluruh item variabel yang digunakan dalam penelitian ini adalah reliabel.

3) Hasil Uji Regresi Linear Berganda

Regresi Linear Berganda terdiri dari 2 variabel penelitian atau lebih, dengan catatan bahwa variabel dependen hanya satu dan variabel independen lebih dari satu. Adapun persamaan regresinya adalah sebagai berikut:

$\mathrm{Y}=\mathrm{a}+\mathrm{b}_{1}\left(\mathrm{X}_{1}\right)+\mathrm{b}_{2}\left(\mathrm{X}_{2}\right)+\mathrm{b}_{3}\left(\mathrm{X}_{3}\right)+\mathrm{e}$ 
Tabel 7. Hasil Uji Analisis Regresi Linear Berganda Coefficients $^{\mathrm{a}}$

\begin{tabular}{|ll|r|r|r|r|r|}
\hline \multirow{2}{*}{ Model } & \multicolumn{2}{|c|}{ Unstandardized Coefficients } & \multicolumn{1}{c|}{$\begin{array}{c}\text { Standardized } \\
\text { Coefficients }\end{array}$} & \multirow{2}{*}{} \\
\cline { 3 - 5 } & \multicolumn{1}{|c|}{$\mathrm{B}$} & \multicolumn{1}{c|}{ Std. Error } & \multicolumn{1}{c|}{ Beta } & \multicolumn{1}{c|}{ Sig. } \\
\hline 1 & (Constant) & 4,981 & 2,093 & & 2,380 &, 020 \\
& Beauty Vlogger &, 278 &, 130 &, 211 & 2,136 &, 036 \\
& Citra Merek &, 243 &, 084 &, 279 & 2,879 &, 005 \\
& Label Halal &, 208 &, 091 &, 228 & 2,276 &, 025 \\
\hline
\end{tabular}

a. Dependent Variable: Minat Beli

Sumber : Data yang diolah SPSS 22, 2019

Berdasarkan Tabel tersebut dapat diketahui bahwa persamaan regresi dari Beauty vlogger, Citra Merek, dan Label Halal secara parsial terhadap Minat Beli yaitu:

$\mathrm{Y}=4,981+0.278 . \mathrm{X} 1+0.243 . \mathrm{X} 2+0.208 . \mathrm{X} 3+\mathrm{e}$

Dari persamaan regresi diatas dapat diartikan bahwa:

$\mathrm{a}=$ konstanta sebesar 4,981 artinya jika variabel Beauty vlogger (X1), Citra Merek (X2), dan Label Halal (X3) nilainya adalah 0 atau tidak ikut mempengaruhi variabel Minat Beli (Y). maka nilai variabel Minat Beli (Y) nilainya sebesar 4,981 .

$\mathrm{X}_{1}=$ Nilai koefesien regresi variabel Beauty vlogger (X1) sebesar 0.278, artinya jika variabel independen X1 bernilai 0 maka nilai konstan $=4,981$ dan variabel Beauty vlogger (X1) mengalami kenaikan 1 satuan, maka variabel dependen (Y) akan mengalami kenaikan sebesar 0.278.

$\mathrm{X}_{2}=$ Nilai koefesien regresi variabel Citra Merek (X2) sebesar 0.243, artinya jika variabel independen X2 bernilai 0, maka nilai konstan $=4,981$ dan variabel Citra Merek (X2) mengalami kenaikan 1 satuan, maka variabel dependen (Y) akan mengalami kenaikan sebesar 0.243.

$\mathrm{X}_{3}=$ Nilai koefesien regresi variabel Label Halal (X3) sebesar 0,208, artinya jika variabel independen X3 bernilai 0 , maka nilai konstan $=4,981$ dan variabel Label Halal (X3) mengalami kenaikan 1 satuan, maka variabel dependen (Y) akan mengalami penurunan sebesar 0.208.

\section{PEMBAHASAN}


Analisa yang telah dilakukan dengan menggunakan Uji Validitas, Uji Reliabilitas, Uji Normalitas, Uji Multikolineritas, Uji Heterokedastisitas, Uji Autokorelasi, Uji Korelasi dan Regresi, Uji Koefisien Determinasi serta Uji Hipotesis dari masingmasing variabel, maka dapat disimpulkan sebagai berikut:

1) Pembahasan atas Pengaruh Beauty vlogger Terhadap Minat Beli Berdasarkan semua pengujian yang telah dilakukan menggunakan SPSS versi 22.0 diatas tentang pengaruh Beauty vlogger terhadap Minat Beli, hasil uji hipotesa tingkat signifikan $(0,036<0,05)$, sehingga dapat disimpulkan bahwa hipotesa yang di ajukan oleh peneliti diterima yaitu terdapat pengaruh yang signifikan dan positif antara variabel Beauty vlogger terhadap Minat Beli Produk Kosmetik Wardah. Dikarenakan semakin baik beauty vlogger yang dimiliki, maka semakin meningkat minat beli suatu produk dan sebaliknya.

Hasil ini sesuai dengan penelitian yang dilakukan oleh Rumondang Eliza Maria Sinaga, Andriani Kusumawati, dalam artikel yang berjudul Pengaruh youtube beauty vlogger terhadap minat beli konsumen dan dampaknya terhadap keputusan pembelian, Terbit di Jurnal Administrasi Bisnis (JAB) Vol. 63 No.1 Oktober 2018, menghasilkan kesimpulan bahwa Youtube beauty vlogger berpengaruh signifikan terhadap minat beli konsumen, semakin baik kredibilitas seorang yotube beauty vlogger maka akan mengakibatkan minat beli konsumen terhadap produk yang diulas oleh youtube beauty vlogger semakin tinggi pula.

2) Pembahasan atas Pengaruh Citra Merek Terhadap Minat Beli

Berdasarkan semua pengujian yang telah dilakukan menggunakan SPSS versi 22.0 diatas tentang pengaruh Konten Beauty vlogger terhadap Minat Beli, hasil uji hipotesa tingkat signifikan $(0,005<0,05)$, sehingga dapat disimpulkan bahwa hipotesa yang di ajukan oleh peneliti diterima yaitu terdapat pengaruh yang signifikan dan positif antara variabel Citra Merek terhadap Minat Beli Produk Kosmetik Wardah. Dikarenakan semakin baik citra merek yang dimiliki, maka semakin meningkat minat beli suatu produk dan sebaliknya.

Hasil ini sesuai dengan penelitian yang dilakukan oleh Rosmaya Adriyati, Farida Indriani, dalam artikel yang berjudul Pengaruh Electronic Word Of Mouth terhadap Citra Merek dan Minat Beli pada Produk Kosmetik Wardah, 
Terbit di Journal Diponegoro Of Management, Vol.6, No. 4, Tahun 2017, menghasilkan kesimpulan bahwa variabel electronic word of mouth memiliki pengaruh signifikan terhadap citra merek dan minat beli. Citra merek memiliki pengaruh signifikan terhadap minat beli.

3) Pembahasan atas Pengaruh Label Halal Terhadap Minat Beli

Berdasarkan semua pengujian yang telah dilakukan menggunakan SPSS versi 22.0 diatas tentang pengaruh Konten Beauty vlogger terhadap Minat Beli, maka didapat hasil uji hipotesa tingkat signifikan $(0,025<0,05)$, sehingga dapat disimpulkan bahwa hipotesa yang di ajukan oleh peneliti diterima yaitu terdapat pengaruh yang signifikan dan positif antara variabel Label Halal terhadap Minat Beli Produk Kosmetik Wardah. Dikarenakan semakin baik label halal yang dimiliki, maka semakin meningkat minat beli suatu produk dan sebaliknya.

Hasil ini sesuai dengan peneitian oleh Premi Wahyu Widiyaningrum, dalam artikel yang berjudul Pengaruh Label Halal dan Celebrity Endorses terhadap Keputusan Pembelian, Terbit di Jurnal Ekonomi Syariah Indonesia, Vol.VI, No. 2, Tahun 2016, menghasilkan kesimpulan bahwa variabel label halal $\left(\mathrm{X}_{1}\right)$ adalah signifikan pengaruhnya dan positif hubungannya terhadap keputusan pembelian (Y) dan variabel celebrity endorser $\left(\mathrm{X}_{2}\right)$ adalah signifikan pengaruhnya dan positif hubungannya terhadap keputusan pembelian (Y).

\section{SIMPULAN}

a. Terdapat pengaruh yang signifikan antara beauty vlogger (X1) terhadap minat beli (Y). Dilihat dari tingkat signifikan sebesar $0,036<0,05$, jadi terdapat pengaruh positif antara beauty vlogger terhadap minat beli, maka semakin meningkatnya beauty vlogger semakin meningkat pula minat beli dalam pembelian produk.

b. Terdapat pengaruh yang signifikan antara citra merek (X2) terhadap minat beli (Y). Dilihat dari tingkat signifikan sebesar $0,005<0,05$, jadi terdapat pengaruh positif antara citra merek terhadap minat beli, maka semakin meningkatnya citra merek semakin meningkat pula minat beli dalam pembelian produk.

c. Terdapat pengaruh yang signifika antara label halal (X3) terhadap minat beli (Y). Dilihat dari tingkat signifikan sebesar $0,025<0,05$, jadi terdapat pengaruh 
positif antara label halal terhadap minat beli, maka semakin meningkatnya label halal semakin meningkat pula minat beli dalam pembelian produk..

\section{DAFTAR PUSTAKA}

Abdurrahman, N.H. 2015. Manajemen Strategi Pemasaran. Bandung : Pustaka Setia

Adriyati, R. \& Indriani, F. 2017. Pengaruh Electronic of Mouth terhadap Citra Merek dan Minat Beli pada Produk Kosmetik Wardah. Diponegoro joutnal of management, Vol. 6, no. 4. Hal 1-14

Anggraeni, D.R., Pangestuti, E., \& Devita, R.D.L. 2018. Pengaruh Endorsement Beauty vlogger terhadap Minat Beli Make Up Brand Lokal. Jurnal Administrasi Bisnis (JAB), Vol. 60, no.1

Apjii. 2016. Hasil Survei Pengguna Internet

Bulan, L.P.T, Fazrin, K \& Rizal, M. 2017. Pengaruh Label Halal dan Bonus dalam Kemasan terhadap Keputusan Pembelian pada Produk Kinder Joy pada Masyarakat Kota Langsa. Jurnal Manajemen Keuangan, Vol. 6, No. 2

D.P, Wida.PN \& Suartana, W.I. 2014. Pengaruh Kepemilikan Manajerial dan Kepemimpinan Institusional Pada Nilai Perusahaan. E-Jurnal Akuntansi Universitas Udayana, hal 575-590, ISSN: 2302-8556

Dewi, P.S. 2012. Pengaruh Pengendalian Internal dan Gaya Kepepmimpinan Terhadap Kinerja Karyawan SPBU. Jurnal Nominal, Vol 1, Nomor 1

Febriana, M. \& Yulianto, E. 2018. Pengaruh Online Consumer Review oleh Beauty vlogger terhadap Keputusan Pembelian. Jurnal Administrasi Bisnis (JAB) Vol. 58, no. 1

Halalmui. 2019. Informasi Halal

Husna, R \& Dirgantara, B.M.I. 2018. Analisis Pengaruh electronic Word of Mouth di Media Sosial Youtube terhadap Minat Beli Produk Kosmetik Sariayu. Diponegoro Journal of Management, Vol.7, no.3

Kurniawati, D. \& Arifin, N. 2015. Strategi Pemasaran melalui Media Sosial dan Minat Beli Mahasiswa. Jurnal Simbolika Vol. 1, no.2

Nuraina, Dewi. 2012. Pengaruh Kepemilikan Institusional dan Ukuran Perusahaan Terhadap Kebijakan Hutang dan Nilai Perusahaan. Jurnal Akutansi, hal 51-70, eISSN: 2502-6380

Onigbinde dan Odunlami. 2015. The Influnce Brand Image and Promotional Mix On Consumer Buying Decision. British Journal of Marketing Studies, Vol. 3, No. 4, pp 97-109

Paragon-innovation. 2019. The History Of Paragon

Permana, D.H. 2017. Pengaruh Citra Merek Dan Kualitas Produk terhadap Keputusan Pembelian. Jurnal Ilmiah Ekonomi Akuntansi Manajemen Pelita Ilmu, Vol.11, no.2 
Prabawa, A.L. 2015. Perkembangan Teknologi Informasi dan Komunikasi, Inovasi, Kepemimpinan dan Kinerja Perusahaan. Jurnal Pendidikan Ekonomi dan Bisnis, Vol.3. no, 1

Setiyani \& Rediana. 2010. Pemanfaatan Internet sebagai Sumber Belajar. Jurnal Pendidikan Ekonomi Dinamika Pendidikan, Vol. V, no. 2, hal 117-133

Sinaga, M.E.R. \& Kusumawati, A. 2018. Pengaruh Youtube Beauty vlogger terhadap Minat Beli Konsumen dan Dampaknya terhadap Keputusan Pembelian Produk. Jurnal Administrasi Bisnis (JAB), Vol. 63, No. 1

Situmorang, R. J. 2012. Pemanfaatan Intenet sebagai New Media dalam Bidang Politik, Bisnis, Pendidikan dan Sosial Media. Jurnal Administrasi Bisnis (JAB), Vol. 8, no. 1, hal 73-87

Sokolova, K \& Kefi, H. 2019. Instagram and Youtube Bloggers Promote it, Why Should I Buy? How Credibility and Parasocial Interaction Influence Purchase Intentions. Journal of Retailing and Consumer Service

Sugito, Yogi. 2013. Metodologi Penelitian. Malang : Universitas Brawijaya Press

Sugiyono, 2015. Metode Penelitian. Bandung :Alfabeta

Sugiyono. 2013. Metode Penelitian Kuantitatif, Kualitatif dan R\&D. Bandung; Alfabeta. CV

Sujarweni, Wiratna. 2014. Metodologi Penelitian. Pustaka Baru Press

Sukesti, S \& Budiman, M. 2014. The Influence Halal Label and Personal Religiousity on Decision on Food Product in Indonesia. International Journal of Business, Economic and Law, Vol. 4, ISSN 2289-1552

Sunarti, Wibowo, E., \& Utami, S.S. 2019. Pengaruh Beauty vlogger terhadap Minat Beli Produk Kosmetik Wardah dengan Citra Merek sebagai Variabel Mediasi. Jurnal Ekonomi dan Kewirausahaan, Vol. 19, no. 4, hal 579-589

Susanto, Singgih. 2012. Aplikasi SPSS Pada Statistik Parametik. Jakarta : PT.Elex Media Kumputindo

Suwati, Yuli. 2013. Pengaruh Kompensasi dan Motivasi Kerja Terhadap Kinerja Karyawan Pada PT. Tunas Hijau Samarinda. eJournal Ilmu Administrasi Bisnis, Vol. 1, No. 1

Tarigan, S.D.E. 2016. Pengaruh Gaya Hidup, Label Halal dan Harga terhadap Keputusan Pembelian Kosmetik Wardah. Jurnal Konsep Bisnis dan Manajemen, Vol.3, No.1

Tio, Farid, Aditya, Henry, Hendra, Arda dan Dhanang. Teknologi Komunikasi dan Realitas Semu Media Massa. Surabaya: Garuda Mas Sejahtera

Widiyaningrum, W.P. 2016. Pengaruh Label Halal dan Celebrity Endorses terhadap Keputusan Pembelian. Jurnal Ekonomi Syariah Indonesia, Vol.VI, No. 2 